of these phenomena during the several hours of the day for the twenty years ending I884:-

\begin{tabular}{|c|c|c|c|c|c|c|c|}
\hline Hours. & 咄 & 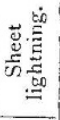 & 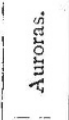 & Hours. & 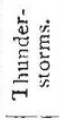 & 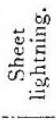 & 这 \\
\hline & $\begin{array}{l}\text { Sumx } \\
\text { June, } \\
\text { Aug }\end{array}$ & $\begin{array}{l}\text { er- } \\
\text { July, } \\
\text { ist. }\end{array}$ & Year. & & $\begin{array}{c}\text { Sum } \\
\text { June } \\
\text { Aus }\end{array}$ & $\begin{array}{l}\text { July, } \\
\text { Just. }\end{array}$ & Year. \\
\hline Midt. to I a.m. & 9 & $x_{4}$ & to & Noon to I p.m. & 26 & $\circ$ & o \\
\hline I to $2 \mathrm{a} . \mathrm{m}$ & 5 & 4 & 2 & x to 2 p.m. & 27 & 。 & o \\
\hline 2 to $3 \mathrm{a} . \mathrm{m}$. & 5 & I & 2 & 2 to 3 p.m. & 21 & 2 & $\circ$ \\
\hline 3 to 4 a.m. & 6 & $\tau$ & I & $3^{\mathrm{ts}} 4$ p.m. & 29 & 2 & o \\
\hline 4 to $5 \mathrm{a} . \mathrm{m}$. & 4 & 0 & $c$ & 4 to 5 p.m. & 17 & 2 & o \\
\hline 5 to 6 a.m. & 6 & $\circ$ & I & 5 to 6 p.m. & 22 & 4 & 5 \\
\hline 6 to 7 a.m. & 4 & o & I & 6 to $7 \mathrm{p} . \mathrm{m}$. & 22 & 3 & 10 \\
\hline 7 to 8 a.m. & 7 & I & 0 & 7 to 8 p.m. & 5 & 12 & 26 \\
\hline 8 to 9 a.m. & 5 & $\circ$ & 0 & 8 to 9 p.tn. & 3 & 22 & $3^{x}$ \\
\hline 9 to xo a.m. & 8 & $\circ$ & 0 & 9 to ro p.m. & 5 & $4 \mathrm{I}$ & 27 \\
\hline ro to $x \mathrm{I} \mathrm{a} . \mathrm{m}$. & 7 & I & o & Io to $\mathrm{rr} \mathrm{p} . \mathrm{m}$. & 5 & 40 & 25 \\
\hline Ir to noon. & 21 & I & o & Ir to mi lnight & 5 & 26 & 16 \\
\hline
\end{tabular}

Thus the daily maximum for thunderstorms is from about noon to 7 p.m., being tie period of the day covered by the afternoon minimum of atmospheric pressure in summer ; but the maximum for sheet lightning is from 8 p.m. to midnight, being the period embraced by the afternoon maximum of pressure. The absolute daily maximum for sheet lightning, it will be observed, does not occur till from 9 to I I p.m., or till so ne time after dusk, and cannot therefore be accounted for by increased visibility as darkness sets in. The opinion is widespread that sheet lightning is merely the reflection of a distant flash of lightning. The Oxf rrd observations show, however, that only a small per centage of all the cases admit of being explained in this way. In connexion with the well-defined maximum from 9 to $\mathrm{I} \mathrm{p} . \mathrm{m}$. it may be remarked that there is no region of the globe nearer Oxford than America where thunderstorms with the accompanying true lightning have the daily maximum at the same physical time, 9 to II p.m. G.M.T., when sheet lightning has its daily maximum at Oxford.

The curve for auroras has its diurnal maxim!m substantially at the same time as sheet lightning, or during the time of the evening maximum of pressure. The agreement of these two maxima with this portion of the daily curve of pressure is all the closer when it is considered that the evening maximum of pressure is from one to two hours later in summer when the sheet lightning was observed than in the autumn and spring months when the great majority of auro:as occur. These reiults are of the greatest importance with respect to recent theories regarding thunderstorms, and to suggested connexions between the aurora in arctic and sub-arctic regions and the lightnings of low latitudes. The time of occurrence of the maxima of aurora and sheet lightning from 9 to I I p.m. indicates, perhaps, a more direct connexion between these phenomena and the evening maximum of pressure than has been suspected. This maximum is mainly due to an overflow of upper aërial currents back to eastward from the longitudes to westward, where at the time the afternoon pressure is at the mini num ("Encyc. Britt.," Meteorology, p. 122); and hence at these hours there is more aqueous vapour spread through the higher regions of the atmosphere in its gaseous and fluid states, and also in the solid state of minute spicules of ice, even though no cloud in the finest pencilled forins of the cirrus be visible.

\section{UNIVERSITY AND EDUCATIONAL} INTELLIGENCE

CAMbridge.-Drs. Routh and Glaisher, Prof. J. J. Thomson, and Mr. A. R. Forsyth have been appointed Examiners in Part II. of the Mathematical Tripos of I888.

The following appointments of Natural Science Examiners have been made :-Physics: Profs. J. J. Thomson and W. G. Adams. Cheinistry: Prof. H. E. Armstrong and Mr. H. I. H. Fenton. Mineralogy: Messrs. T. W. Danby and $\mathrm{H}$. A. Myers (British Museum). Botany: Prof. I. B. Balfour and Dr. S. H. Vines. Physiology: Dr. W. H. Gaskell and Prof. G. F. Yeo. Zoology: Messrs. H. Gadow and W. F. R.
Weldon. Geology: Prof. C. Lapworth and Mr. A. Harker. Human Anatomy : Prof. J. Cleland and Dr. A. Hill. Pharmaceutical Chemistry : Mr. Pattison Muir.

At a meeting of the Senate in the Arts School recently, general approval was expressed of the scheme for providing a new room for botanical microscopy. The scheme for new anatomical and physiological rooms was not so entirely approved, some persons wishing to retain the ugly old Anatomical Museum and buildings, and also $c$ nsidering that the requirements of the Medical School had not been sufficiently considered.

Mr. W. Bateson, M.A., Fellow of St. John's College, has been elected to the Balfour Studentship.

Group E (Natural Science), in the Higher Local Examination, attracts a diminishing number of candidates, we are sorry to see. Only 36 presented themselves this year as against 73 in 1879 ; but ro candidates gained a first class this year, as against 4 in 1879: 35 failed then, only 5 this year. Elementary Biology is reported on fairly this year ; but Elementary Chemistry does not seem to have been studied practically, and problems were not satisfactorily dealt with. Only four candidates passed in Physics. The Physiology, Zoology, and Geology papers were well answered; but in Botany the general standard was decidedly low.

\section{SOCIETIES AND ACADEMIES LONDON.}

Entomological Society, November 2.-Dr. D. Sharp, President, in the chair.-Mr. Stevens exhibited a specimen of Acidalia immo ata, L., purcha ed by him some years ago at the sale of the collection of the late Mr. Desvignes. He remarked that specimens of the insect lately captured near Lewes had been described last month by Mr. J. H. A. Jenner as a species new to Britain. - Mr. Adkin exhibited, and made remarks on, a series of male and female specimens of Arctia mentica from co. Cork ; also, for c smparison, two specimens of $A$. mentica from Antrim, and a series of bred specimens from the London district. $-\mathrm{Mr}$. Enoch exhibited a specimen of Calocoris bipunctalus containing an internal parasitic larva.--Dr. Sharp exhibited three species of Coleoptera new to the British list, viz. Octhclius auriculatus, Rey, found some years ago in the Isle of She:pey, but described only quite recently by M. Rey from specimens found at Calais and Dieppe ; Limnius rivularis, Rosenh., found by I)r. J. A. Power at Woking; and Tropiphorus obtusus, taken by himself on the banks of the Water of Cairn, Dumfriesshire.-Dr. Sharp also exhibited a Goliathus recently described by Dr. O. Nickerl as a new species under the name of Goliathus atlas, and remarked that the species existed in several cullections, and had been supposed to be possibly a hybrid between $G$. regizus and $G$. cacicus. - Mr. Eland Shaw exhibited two species of Orthoptera, which had been unusually abundant this year, viz. Nemobius sylvestris, and Tettix subulatus.-Mr. E. B. Poulton exhibited the cocoons of three species of Lepidoptera, in which the colour of the silk had been controlled by the use of appropriate colours in the Iarval environment at the time of spinning up. He said this colour-suiceptibility had been previously proved by him in 1886 in the case of Saturnia carpini, and the experiments on the subject had been described in the Proc. Royal Society, 1887 . It appeared from these experiments that the cocoons were dark brown when the larve had been placed in a black bag; white when they had been freely exposed to light with white surfaces in the immediate neighbourhood. $\mathrm{Mr}$. Poulton stated that other species subjected to experiment during the past season afforled confirmatory results. Thus the larvæ of Eriogasterlanestris had been exposed to white surroundings by the Rev. W. J. H. Newman, and cream-coloured cocoons were produced in all cases; whilst two or three hundred larvæ from the same company spun the ordinary dark brown cocoons among the leaves of the food-plant. In the latter case the green surroundings appeared to act as a stimulus to the production of a colour which corresponded with that which the leaves would subsequently assume. Mr. Stainton suggested that larvæ should be placed in green boxes, with the view of ascertaining whether the cocoons would be green. It had been suggested that the cocoons formed amongst leaves became brown because the larvæ knew what colour the leaves would ultimately become. The discusion was continued by Mr. Waterhouse, Dr. Sharp, Mr. McLachlın, and others. -Mr. S. Klein read "Notes on Ephestia kuhniella," and exhibited a number of living larvæ of the species, which he said 
had been recently doing great damage to flour in a warehouse in the East of London.-Mr. A. G. Butler contributed a paper "On the species of the Lepidopterous genus Euchromia; with descriptions of new species in the collection of the British Museum."-Lord Walsingham communicated a note substituting the generic name Homonymus for the generic name Ankistroshorus - which was preoccupied-used in his "Revision of the genera Acrolophus and Anaphora," recently published by the Society.

PARIS.

Academy of Sciences, November 14.-M. Janssen in the chair.- Note on certain definitions in mechanics, and on the unities in current use, by M. de Freycinet. In supplement to the remarks already made in his treatise on mechanics, the author here deals more fully with the notions involved in such terms as force, weight, mass, bulk, and shows that considerable advantage might be gained by slightly modifying the generally accepted unities. Fresh definitions are suggested of the unities of length, volume, weight, force, velocity, \&c.-On the state of the potassa present in plants and the soil, and on its quantitative analysis, by MM. Berthelot and André. In continuation of a previous communication on this subject, the authors here study the condition and process of analysis of the potassa in living plants, and in the humus produced by their disintegration. - On waterspouts, by M. D. Colladon. In reply to M. Faye's strictures, the author illustrates his views by means of an instantaneous photograph, showing that under certain conditions two waterspouts may be generated, one ascending, the other descending, and crossing each other.-On MM. Houzeau and Lancaster's " Bibliographie Générale de l'Astronomie," by M. Faye. A well-merited eulogium is passed on the authors of this great work, who have earned the lasting gratitude of astronomers for accomplishing their vast undertaking in such a thoroughly satisfactory manner. The Bibliography constitutes a systematized catalogue of all astronumical publications that have appeared from the remotest times down to the present day. Although not absolutely exhaustive, the omissions do not appear on examination to be very numerous ; but unfortunately only 300 copies have been issued of a work which should find a place in every Observatory and in every scientific library in the world. $M$. Houzeau has enriched the first volume with a valuable philosophic history of astronomy, which will be found extremely interesting, especially to those students who have been unable to follow the recent discoveries of specialists on the state of astronomical science amongst the Egyptians, Assyrians, and other ancient peoples. - New nebulæ discovered at the Observatory of Paris, by M. G. Bigourdan. These discoveries have been made during the years $1884-87$ with the equatorial of the West Tower. Most of the nebulæ are very weak, and some, indicated as more or less stellar, might, strictly speaking, be regarded as simple stars, it being often quite impossible to distinguish between a small nebula and a star of small magnitude. The positions are approximately given for the mean equinox of $x 860^{\circ} \mathrm{o}$, in order to facilitate comparison with J. Herschel's "General Catalogue of Nebulæ and Clusters of Stars," and its supplement by Dreyer. -On the theory of magnetism, by M. P. Duhem. From a comparative study of magnetic and diamagnetic bodies the theorem is deduced that all magnetic bodies are attracted from great distances by permanent magnets, but that nothing can be affirmed regarding diamagnetic bodies. A theorem is also established which sets forth the difference between magnetic and diamagnetic bodies, and some remarks are appended regarding the magnetizing of crystals.-Measurement of the heights and movements of clouds in Spitzbergen and Upsala, by M. Nils Ekholın. These comparative studies are based on fifty meteorological observations taken during the Swedish expedition of I882-83 to Spitzbergen, conducted by the author. - On a new method of formation of safranines, by MM. Ph. Barbier and Léo Vignon. Having in a previous communication explained a special method of forming substituted safranines, the authors here describe a new process for producing phenosafranine and its homologues. - On a new artificial serum intended to dilute the blood for the purpose of counting its globules, by M. Mayet. For the serum here described it is claimed that it is free from the disadvantages of others in general use. It consists of distilled water, $100 \mathrm{gr}$. ; neutral phosphate of anhydrous and pure sodium, $2 \mathrm{gr}$. ; with cane sugar to raise the density of the liquid to $\mathrm{I}^{\circ} 085$. -On antipyrine as a remedy against sea-sickness, by $M$. Eugène Dupuy. The author declares that for some time back he has successfully employed this substance as a prophylactic against sea-sickness. He recommends a dose of $3 \mathrm{gr}$. to be taken daily for three days before sailing, to be continued if necessary during the voyage. Without claiming to have discovered an absolute specific, he considers that the success hitherto attending the use of antipyrine justifies the hope that in this substance we possess a more or less efficacious remedy against one of the chief terrors of travelling by sea.

\section{BOOKS, PAMPHLETS, and SERIALS RECEIVED.}

A Dictionary of Place-Names: C. Blackis, $3^{\text {rd }}$ edition (Murray).-Repor of the Commissioner of Adriculture, 1885 (Washington). -The Cremation the Dead: Dr. H. Erichsen (Haynes. Detroit). -D wwn the Great River: Capt. W. Glazier (Hubbard, Philadelphia). - The Creator, and what we may know of the Method of Creation: Dr. W. H. Dallinger (Woolmer).-Primo Saggio sui Ragni Birmani : Prof. T. Thorell (Genova).-Le Pétrole : W. de Fonvielle (Hachette).-Ants, Bees, Dragon-Flies, Earwigs, Crickets, and Flies W. H. Bath (Sonnenschein).-Through Central Asia: Dr. H. Lansdell (Low) -The Volcanic Origin of Epidemics; Are Epidemics Contagious? Dr. Parkin (Low). - Bulletin of the U.S. Fish Commission, vol. vi., 1886 (Wash ington).-Mineralogy: F. Rutley (Murby)-AVertebrate Fauna of Sutherland Caithness, and West Cromarty : Harvie-Brown and Buckley (Douglas). - Bul letin of the U.S. National Museum, No. 32, Catalogue of Batrachians and Reptiles of Central America and Mexico: E.D. Cope (Washington).-Archiv für Pathologische Anatomie und Physiologie, und für klinische Medicin, Hund. Bandes, $Z$ weites Heft (Reimer, Berlin). - Botanische Jahrbücher für Sys tenatik, Pflanzengeschichte, und Pflanzengeographie, Neunter Band, ii. Hef Engelmann, Leipzig). - Transactions of the County of Middlesex Natural History and Science Society, 1886-87 (Mitchell and Hughes). - Records of the Geclogical Survey of India, vol. xx. part 3.-Bulletin of the Californi Academy of Sciences, vol. ii. No. 7 -Annalen der Physik und Chemie, 1887 No. II (Leipzig). - Beiblätter zu den Physik und Chemie, 1887 , No. (Leipzig). - Transactions of the Aviatic Society of Japan, vol, xv. part $x$.

\section{CONTENTS.}

PAGE

Charles Darwin. By Prof. T. G. Bonney, F.R.S. . . 73

Our Book Shelf :-

Roberts : "A Treatise on the Integral Calculus" . . . 75

Todhunter: "Solutions to Problems contained in a

Treatise on Plane Co-ordinate Geometry" . . . . . 75

De Bary : "Lectures on Bacteria" . . . . . . . . . 75

Desmaux : "Mattie's Secret"......... 76

Letters to the Editor:-

Politics and the Presidency of the Royal Society.-Prof. Balfour Stewart, F.R.S. ; Prof. Alex. W. Williamson, F.R.S. . . . . . . . . 76 "The Conspiracy of Silence."-Prof. T. G. Bonney,

F.R.S. . . . . . . . . . . . . . 7

Instability of Freshly-Magnetized Needles.-Prof.

Francis E. Nipher; Prof. Arthur W. Rücker,

F.R.S.

Greek Geometry, - R. T. * * 77

The Chromosphere,-John Evershed, Jun. . . . . 79

Perception of Colour.-C. E. Stromeyer . . . . . . 79

Swifts. -C. B. Witchell . . . . . . . . . . . 79

Note on a Madras Micrococcus, -Edgar Thurston . 79

Catharinea undulata. - J. Reynolds Vaizey . . . . 79

Researches on Meteorites. II. (Illustrated.) By J.

Norman Lockyer, F.R.S. . . . . . . . . . . . 80

Sir Julius von Haast, F. R.S. . . . . . . . . . . 87

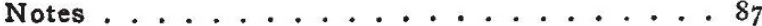

Our Astronomical Column :-

American Observatories . . . . . . . . . 89

U Ophiuchi . . . . . . . . . . . . . . 90

The New Algol Variables . . . . . . . . . . . 990

Astronomical Phenomena for the Week 1887

November 27-December 3 . . . . . . . 90

Grographical Notes . . . . . . . . 90

Meteorological Notes ............ 91

The British Association and Local Societies . . . 9I

The Meteorology of Oxford . . . . . . . . 94

University and Educational Intelligence . . . . 95

Societies and Academies . . . . . . . . . 95

Books, Pamphlets, and Serials Received .. . . 96 